\title{
The Results of Developmental Task Inventory(ITP) For Guidance and Counseling Services at Islamic Boarding Schools
}

\author{
Utami Niki Kusaini ${ }^{1}$ \\ 1, Widya Dharma College of Psychology, Indonesia \\ Correspondingauthor:Niki.utami@yahoo.com
}

\section{AR T I CL E IN F O}

\section{Article history: \\ Received may 2021 \\ Revised june 2021 \\ Accepted july 2021}

\section{Keywords:}

developmental task

inventory,

guidance and counseling

services,

islamicboarding school.

\begin{abstract}
A B S T R A C T
Guidance and counseling service is useful for students in Islamic Boarding Schools but to determine service based on the requirement of students is difficult. This research purposed to describe the results ofDevelopmental Task Inventory(ITP) to help students find developmental tasks that have not been achieved. This research used survey method. The respondents of this research six classes with the amount of 445 students in two Boarding School of Yogyakarta. The results showed that the achievement of development tasks students above the average growth rate of 3.75. The task of development is not yet achieved $(<3.75)$. Based on these results, the researcher sees each class having differences in aspects of development tasks that have not been achievedand require different guidance and counseling services.
\end{abstract}

(C) IJAGC 2021, All right reserved ISSN: 2722-2365 (Online) 2722-2357 (Print)

\section{Introduction}

The education system in Indonesia has three paths, namely: formal education, nonformal education, and informal education. (Hayah K, 2017) reveals that the process of education both formally, informally and non-formally is a pillar for giving birth to a new generation in Indonesia with a strong character. Formal education consists of levels: Basic Education, Secondary Education, and Higher Education. Non-formal education consists of course institutions, training institutions, study groups, centers of community learning activities, and majelistaklim, and similar educational units. Informal education consists of levels: family and environmental education pathways in the form of independent learning activities carried out consciously and responsibly. Non-formal education that offers several educational facilities, one of which is Islamic boarding schools. Islamic boarding schools have a different curriculum than schools in general. Islamic boarding schools integrate the curriculum from the government with a curriculum made by the Islamic Boarding School, so that in addition to being equipped with general knowledge, students can also deepen their religious knowledge. Students who study at Islamic boarding schools are expected to master science and have faith and piety as a provision in living in a community. Islamic boarding schools provide education in dormitories and madrasas, in boarding schools, students learn to be independent, responsible, and socialize with other students who have different 
backgrounds. Whereas in the madrasa the students learn like in school in general. According to (Pavletic et al., 2016) teenagers who enter boarding school preparations grow and learn to take care of themselves in very different circumstances than those who live in homes with families. School students face a variety of problem areas that are seen as common problems covering the fields of language, financial, social, psychological, health, recreation, and academic issues (Lui, 2009; Sherry, et al., 2010; Sovic, 2009).

Students in Islamic Boarding Schools are still in their teens who are looking for an identity. (Fuad et al., 2017) adolescents are synonymous with the era of self-identity confusion. The effect of self-identity disorder among adolescents can be described through misconduct on school discipline. Adolescence is a period in human life whose age and role limits are often not very clear. Adolescence is often regarded as a transitional period. According to Papalia \& Feldman (2014) suggest that adolescence is a transition period that involves physical, cognitive, emotional, and social changes with various forms of social, cultural and economic backgrounds. In line with the above opinion, Santrock (2014) suggests that adolescence is the developmental period is a transition from childhood to adult which involves biological, cognitive, and socio-emotional changes. The characteristics of the santri will greatly influence the selection of management strategies, which are related to how to organize the teaching, to fit the characteristics of a santri (Uno, 2010). Based on this, it can be concluded in general that santri in Islamic boarding schools are grouped in early adolescence, although it does not rule out the possibility that there are certain cases that students have been in middle adolescence or have even entered late adolescence. Students who have an age which is a transition period creates a variety of behaviors because unstable students in controlling emotions and curiosity in new things that have never been encountered before results in the emergence of behaviors that begin to emerge self-character.

Students who have just entered the Islamic Boarding School environment must be able to adjust to life in Islamic boarding schools, but that is not an easy thing for students. The transition from the family environment to the Islamic boarding school will lead to significant changes for the students. According to Darado (2017) reveals that students choose to leave home at the age of thirteen, the transfer of students from the neighborhood of the dormitory environment can make them feel marginalized in both environments. The tight schedule received by the students had another impact on his life. According to Kanga (2017) that boarding schools are expected to be able to implement guidance and counseling services to help students adjust to the school environment. Every day students are required to take part in activities starting from waking up to going back to sleep which has been arranged in such a way that there is no time wasted, the problem is that there are students who are unable to adjust and carry out activities in Islamic boarding school life, students who experience learning problems, students who need knowledge of their talents and interests, students who are difficult to socialize with peers and seniors, there are students who have difficulty choosing extracurricular activities that are good for themselves.

That problem also resulted in students not being able to develop optimally in the dormitory or madrasa, therefore the students needed guidance and counseling services that fit their needs. Collins et al (2001) state that carrying out a comprehensive needs assessment and incorporating the results into a comprehensive program plan not only benefits student development but also increases academic achievement. Seeing the problems that have been identified above, it is necessary to provide guidance and counseling services that are following the needs of santri so that students can develop optimally spiritually and intellectually by what is expected by guidance and counseling teachers and parents, and does not lead to negative actions. Cantres (2015) suggests that students have different developmental needs in primary, secondary, and high school, guidance and counseling services at that level can have 
different goals. According to Alavi \& Mansor (2011) Differences between cultures can lead to interpersonal experiences and intrapersonal conflicts that occur between students. The needs of students are the basis for conducting guidance and counseling services carried out by school counselors. The competencies that must be possessed by school counselors at Islamic Boarding Schools are understanding the students in-depth, namely understanding the possibilities of problems being faced by the students. Through understanding the obstacles to the developmental tasks faced by the students, the school counselor can then determine the guidance and counseling services that are following the needs of the students, both preventive, development, and curative, so that students are expected to develop their potential optimally.

Guidance and counseling services at Islamic Boarding School are very beneficial to students, teachers, and stakeholders at Islamic Boarding School. Kitson (Shrivastava, 2003) argues that guidance is an attempt to individualize education. Each pupil should be helped to develop himself to the maximum possible degree in all respects. School counseling programs that use data to determine program components, measure student learning, monitor the impact of interventions, and inform stakeholders about the impact of the work being done have the accountability system components in place. Ensuring that students, parents, teachers, and administrators all know the many ways that the school counseling program is supporting and promoting student success creates program accountability and future viability (Dimmit et al., 2007). The main purpose of guidance and counseling services in schools is to provide support to the achievement of personal maturity, social skills, academic ability, and lead to the formation of individual career maturities that are expected to be useful in the future (Fatur Rahman, 2009). Kim \& Lambie (2018) to prevent school counselors from experiencing feelings of burnout, identifying relevant factors is important. In line with the opinion above to be able to provide the services by the needs of students of school, the counselor can use instruments that are already standard.

Guidance and counseling services have several functions. Including the function of understanding, prevention, distribution, adjustment, improvement, development, and maintenance (Suherman, 2010). Mudjiran (2007) explains that one of the tasks of development that must be achieved in the adolescent period is to have a set of values and ethical systems that guide the behavior in running a social life. If in this period teenagers do not behave by the task of moral development, then one will experience delays in moral development. Teenagers who are developing often appear resistant attitude, anxiety, and unstable. Salvia, Ysseldyke\& Bolt (2010) revealed that assessment is a critical practice engaged in to match instruction to the level of students' skills, monitoring student progress, modifying instruction, and working hard to enhance student competence. Sofia et al., (2017) children's value systems develop through youth and influence attitudes and actions.

The instruments that can help school counselors identifying obstacles to the developmental tasks faced by students using Developmental Task Inventory (ITP). Komalasari, et al (2011) and Supriatna (2013) Developmental Task Inventory(ITP) is an instrument used to understand individual and group developmental levels, identify problems that impede development, and assist troubled students in solving the task of its development. Developmental Task Inventory (ITP) is an instruments that have already been tested the validity of and reliability. This instrument was developed by the Development Team of Pendidikan Indonesia University. Preparation is intended to support guidance and counseling activities in schools. By knowing the level of achievement of the learners, it is expected that the counselor has an awareness that the program and guidance and counseling services in the school should be based on the needs and development of learners. Instrument developmental 
refers to the self-development theory of Lovinger which consists of seven levels (SunaryoKartadinata et al., 2003). Lovinger's theory was used by Gfellner and Armstrong (2012) about ego development which reflects the attitude of an individual is looking at themselves and social reality. Data obtained from ITP instruments were then analyzed using ATP. According to Mamat Supriatna (2011: 55) the developmental tasks of junior high school students include faith and piety to God Almighty consisting of loving others, humility, honesty, discipline, emotional independence consisting of emotional atmosphere facing disappointment, social interaction, threats and respecting people. without depending on it, intellectual maturity consists of thinking critically, making decisions, deliberation (democratic), understanding the rights and obligations of students.Guidance and counseling have a service strategy that can help students in facing obstacles or problems they experienced. The counseling and guidance counseling strategy includes classical guidance, group guidance, large/cross-class guidance, individual counseling, group counseling. Counseling and guidance services at the school level, including in the area of tutoring, are directed to meet student needs (Cobia \& Handerson, 2003; Gysbers \& Handerson, 2006).

This research purposed to describe the results of Developmental Task Inventory (ITP)to help students find developmental tasks that have not been achieved. Developmental Task Inventory (ITP) an instrument of guidance and counseling services has been used by the school counselor to reveal aspects of the developmental tasks of students, guidance, and counseling services. According to William J. Kolarik (Nurihsan, 2006) the quality of guidance services will get recognition if guidance and counseling service can meet what is expected by the counselee. Administering Developmental Task Inventory (ITP) the author does to describe the condition of the pitch to 445 students comprising of six classes in one of the Islamic Boarding schools in the city of Yogyakarta on 06 November 2017 shows conditions that concern. Research or preliminary data from the overall Class VII shows that the achievement of the tasks of the development students above the average level of development is 3.72. A development task is still below the average of the duties the development of $(<3.72)$. Note there are five aspects of developmental tasks not yet achieved include: 1) The foundation of religious life with the level of development reached $3.48 ; 2)$ The cornerstone of ethical behavior with the level of development reached 3.68; 3) Emotional maturity with the level of development reached $3.67 ; 4)$ Awareness of responsibility with the level of development reached $3.51 ; 5$ ) Social role as male or female $3.69 ; 6)$ Insight and career preparation with the level of development reached 3.64. From the ten existing development only task four is reached, and that that will be a problem or barrier for students in its development. Harum, Saman, Malik (2015) found that also related to the research results Chris, Megan, Izhar (2018) an adult ego development has a considerable role in educational leadership practice; can inform the analysis of educational leadership practice and development; and has valuable explanatory power. The difference with this study is that the study did not use a feasibility test and a small group test because the researcher only described the results of the ITP instrument on the developmental tasks of students.

The difference with this study is that research not only an adult ego development but all aspects of student development tasks. The condition of the Developmental Task Inventory (ITP) students in Islamic Boarding School each class is different from the overall results class and should be able to complete through the organizing of guidance and counseling services following the needs of each class. Associated with it, the purpose of the study is to describe: (1) the results data of the Developmental Task Inventory (ITP) concerning the tasks of development experienced by students in Islamic Boarding Schools, (2) the utilization of the results of the Developmental Task Inventory(ITP) to find the task of the development of students who have not yet reached. 


\section{Method}

This research used a survey method. Developmental Task Inventory (ITP) is one type of research conducted by many researchers in the field of education. The survey is only to record the data and then try to analyze and interpret the data to then take the conclusions from the data. According Sugiyono (2014) data collection techniques for survey research methods can be done with interviews, questionnaires, and observations. Survey research was conducted to draw general conclusions or generalizations of the specified samples (Suryana\&Priyatna, 2008). Meanwhile, according to Sukmadinata (2016) survey is used to collect data or information about a large population by using a relatively small sample. In line with the above expert opinion, Margono (2014) argues that a survey is a research method that aims to achieve generalization, by making a quantitative comparison of data collected by uniform questioning procedures.

Lodico, Spaulding, \& Voegtle (2010) descriptive survey research is one of the most common types of quantitative research education. There are different types or designs of survey studies. The most common design is the one-shot design, in which the researcher after piloting the survey, administers it once to the sample. Follow-up studies and longitudinal survey studies are designs that follow the same sample over time. Designs that select different samples over time include trend and cohort surveys. Design that follows the same or different samples over time both requires surveys to be administered multiple times. Survey researchers need to be concerned about the response rate or the number of surveys that participants fill out and return.

The instrument used in this research is Developmental Task Inventory (ITP) instrument that has been standardized in guidance and counseling, validity and reliability have been tested. This research was conducted on 2 boarding schools in Yogyakarta city, samples taken from each boarding school as much as 6 classes, consisting of 217 students and 228 students. So the total number of samples that researchers took was as many as 445 students. This study was conducted on 6-18 November 2017. After conducting data retrieval with ITP instrument then the researcher went on to analyze the data using ATP application of Developmental Task Inventory. An initial assumption is that each student has different needs from one to another, and thus different counseling and guidance services are needed according to the needs of the students. This study cannot examine the task of class VII student's development in PondokPesantren in Yogyakarta.

\section{FindingsandDiscussion}

Findings

Basically, students in Islamic Boarding School are in the development period. The task of students development comes from physical maturity, psychic maturity, emotional maturity, community or cultural demands, and individual values or aspirations. The process of development does not always go smoothly without any problems or in line with expectations, potential, and values adopted. Therefore, many things must be completed during the development period. The main result of this research is the discovery of the task of student development that has not been achieved and it will make the students difficulties in reaching the next stage of development.

Individual development will be a great influential in his life. Based on survey results conducted using the Developmental Task Inventory instrument found five out of 10 developmental tasks that have not been achieved. A total of six classes students experience difficulty in achieving developmental tasks. Development tasks that have not been achieved or resolved none of which are below from the five aspects and there are even classes that have six aspects of developmental tasks have not been achieved. If the existing development tasks 
can't be solved then students will have difficulty in completing development in the next stage. The adverse effects of non-completion of individual developmental tasks one of which will appear to be a problem in learning and the social field.

The problem has not been achieved developmental tasks students at Islamic Boarding Schools in Yogyakarta would need guidance and counseling services and handling problems effectively by teacher guidance and counseling. Given the impact of the unfinished development task is able to disrupt the process of daily activities and disrupt its duties. After the researchers analyzed the data obtained, found many developmental tasks that have not been achieved, in reality school counselor has not provided guidance and counseling services in accordance with the needs of students. The following is the inventory analysis of the developmental tasks that the researcher classifies into the class and the whole class. Table 1 the results of Developmental Task Inventory (ITP) of all class VII in Islamic Boarding Schools $\mathrm{X}$, as follows.

Table 1. Results of Developmental Task Inventory (ITP) Class VII in Islamic Boarding Schools

\begin{tabular}{|c|c|c|c|c|c|c|c|c|c|c|c|}
\hline \multirow[b]{3}{*}{ Class } & \multicolumn{10}{|c|}{ Aspects of Student Development } & \multirow[b]{3}{*}{$\begin{array}{l}\text { Averag } \\
\text { e } \\
\text { Develo } \\
\text { pment } \\
\text { Tasks } \\
\text { Achiev } \\
\text { ed }\end{array}$} \\
\hline & 1 & 2 & 3 & 4 & 5 & 6 & 7 & 8 & 9 & 10 & \\
\hline & $\begin{array}{l}\text { Foun } \\
\text { datio } \\
\text { n of } \\
\text { Religi } \\
\text { us } \\
\text { Life }\end{array}$ & $\begin{array}{l}\text { Corne } \\
\text { rston } \\
\text { e of } \\
\text { Ethic } \\
\text { al } \\
\text { Beha } \\
\text { vior }\end{array}$ & $\begin{array}{l}\text { Emoti } \\
\text { onal } \\
\text { Matu } \\
\text { rity }\end{array}$ & $\begin{array}{l}\text { intell } \\
\text { ectua } \\
\text { l } \\
\text { matu } \\
\text { rity }\end{array}$ & $\begin{array}{l}\text { Awar } \\
\text { eness } \\
\text { of } \\
\text { Resp } \\
\text { onsib } \\
\text { ility }\end{array}$ & $\begin{array}{l}\text { Social } \\
\text { Role as } \\
\text { Male or } \\
\text { Femle }\end{array}$ & $\begin{array}{l}\text { Self- } \\
\text { Accept } \\
\text { ance } \\
\text { and } \\
\text { Develo } \\
\text { pment }\end{array}$ & $\begin{array}{l}\text { Indepe } \\
\text { nden of } \\
\text { Econo } \\
\text { mic } \\
\text { Behavi } \\
\text { or }\end{array}$ & $\begin{array}{l}\text { Insight } \\
\text { into } \\
\text { Career } \\
\text { Prepar } \\
\text { ation }\end{array}$ & $\begin{array}{l}\text { Maturit } \\
\text { y of } \\
\text { Relatio } \\
\text { nships } \\
\text { with } \\
\text { Peers }\end{array}$ & \\
\hline VII A & 3.471 & 3.614 & 3.702 & 3.702 & 3.555 & 3.658 & 3.919 & 3.599 & 3.526 & 3.838 & 3.644 \\
\hline VII B & 3.47 & 3.527 & 3.47 & 3.629 & 3.508 & 3.689 & 3.826 & 3.72 & 3.598 & 3.799 & 3.623 \\
\hline VII C & 3.455 & 3.724 & 3.828 & 3.672 & 3.724 & 3.657 & 3.978 & 3.922 & 3.724 & 4.067 & 3.775 \\
\hline VII D & 3.566 & 3.861 & 3.83 & 3.889 & 3.521 & 3.653 & 4.177 & 3.906 & 3.747 & 4.226 & 3.837 \\
\hline VII E & 3.47 & 3.728 & 3.78 & 3.836 & 3.545 & 3.668 & 4.108 & 3.713 & 3.638 & 4.127 & 3.761 \\
\hline VII F & 3.349 & 3.733 & 3.957 & 3.927 & 3.681 & 3.668 & 4.259 & 3.793 & 3.797 & 4.323 & 3.849 \\
\hline $\begin{array}{l}\text { All of } \\
\text { Class } \\
\text { VII }\end{array}$ & 3.475 & 3.711 & 3.753 & 3.761 & 3.587 & 3.663 & 4.036 & 3.785 & 3.676 & 4.069 & 3.75 \\
\hline
\end{tabular}

The results obtained after analyzing the data using the ATP application seen in Table 1 that each class has different in the stage of achieving aspects of developmental tasks, this can be used as a reference for teacher's guidance and counseling in providing services in accordance with the needs of each class. The results of the analysis of the first aspect of the foundation of religious life: the entire class VII have difficulty in achieving this developmental task. The second aspect is the foundation of ethical behavior: only class VII D can attain developmental tasks at this stage, while classes VII A, VII B, VII C, VII E, VII F still have not achieved the task of development but because only one class is new is achieved then in the table the whole class seems to have difficulty to achieve the task of development, the third aspect is emotional maturity: there are two classes that have difficulty to achieve the development task of class VII B with the average level of development tasks $(<3.623)$, the fourth aspect intellectual maturity: class VII C which has not reached the developmental task on this aspect with the average developmental tasks below $(<3.775)$, the fifth aspect of responsibility awareness: the entire class VII has difficulty in achieving the task of development of the fifth aspect, the sixth aspect of the social role as male or female: the class that reaches this aspect is only class VII A and class VII B then from it on the table the overall class VII shows that the whole class does not achieve developmental tasks and requires responsive service. 
The seventh aspect of self-acceptance and development: in this aspect the students of class VII have achieved their development task well. The eighth aspect is the independence of economic behavior: class VII A, VII E, VII F which has not reached the task of development at this stage. The ninth aspect of career preparation insight: the entire class VII has difficulty in developmental tasks on the ninth aspect. The tenth aspect is the maturity of relationships with peers: in this aspect the entire class VII has achieved the task of development well but the seventh-grade students still need guidance and counseling services related to peers. Of the ten aspects of existing development tasks, two aspects are achieved in the overall class VII in Islamic Boarding Schools. Given the results of needs analysis is expected school counselor can develop strategies in providing services in accordance with the needs of each class or from the overall class, and school counselor can classify which aspects should be given counseling and counseling services as soon as possible to prevent obstacles or difficulties that will occur if it is not immediately followed up.

\section{Discussion}

This is like to the research conducted by Utomo, Prayitno,\& Effendi (2017) the results of AUM PTSDL for guidance and counseling service quality score of the high school student learning activities in Padang is in low category or less once an average of $36,30 \%$. Student response in the form of BMB3 student dynamics to AUM PTSDL result material is positive, school counselor welcomes the result of AUM PTSDL students and use it for implementing of BK service to them through various types of services and supporting activities in certain service format. research results by Ardi, Ibrahim \& Said (2012) in his research suggests that the achievement of the task of social development of students with peer groups in the class XI SMA Negeri 1 Padang regarding the ability to foster a more mature relationship with peers and the ability to carry out social roles according to gender in general has been achieved, although in some students still not achieved optimally. Then, there are six questionnaires responded by the students are under the classification of the level of achievement that has been set, so that can be prioritized in the guidance and counseling program.

In line with the research above, Putra and Ramdani (2014) said that the fulfillment of developmental tasks that should be carried out by adolescents must be accompanied by guidance they can get from the people around them, so that the fulfillment of developmental tasks can be in accordance with the values and norms that apply in the community. Environment in which they carry out life activities. Looking at some of the studies above, according to Oluwafemi, Akindele, \& Ayodeji (2017) shows that there is a significant difference between single parenting and schoolchildren's task performance, there is a significant difference between parent's socioeconomic status and task performance, and there is a significant relationship between schoolchildren from separated homes and task performance. It is one of the duties of guidance and counseling teachers to provide guidance and counseling services according to student needs so that student developmental tasks are achieved and can assist students in overcoming obstacles that interfere with their lives. It is one of the duties of guidance and counseling teachers to provide guidance and counseling services according to student needs so that student developmental tasks are achieved and can assist students in overcoming obstacles that interfere with their lives.

\section{Conclusion}

Students in Islamic Boarding Schools will experience obstacles in their lives if they have not been able to complete the task of development in the early stages because the developmental tasks of each other are interconnected. It is in need of assistance from guidance and counseling teachers to provide counseling services based on need. The task of student development is identified by organizing a task-based developmental instrument 
commonly used by school counselor at Islamic Boarding Schools. Instrument used is Developmental Task Inventory of Junior High School Students. This study identifies the developmental tasks of all VII classes that have not been reached by students in Islamic Boarding Schools in Yogyakarta covering aspects of religious life base 3.475, aspect of ethical behavioral basis 3.711, aspect of responsibility awareness 3,587, aspects of social role as male or female 3.663, aspect of insight and preparation career 3,676. It shows that students in Islamic Boarding Schools have difficulties and difficulty in completing the existing development tasks, and this will have an impact on their daily life. These barriers and difficulties should be handled by school counselor using existing service strategies. Identifying the developmental tasks of students in Islamic Boarding Schools will greatly assist school counselor in making guidance and counseling programs and can facilitate students in completing their development tasks that have not been achieved but a synthesis of key points.

\section{References}

Akindele, O., Iwayemi, A., \& Idoko, J. 0. (2017). Influence of separated homes on task performance and personality development of school children in Ondo metropolis. IFE Psycholog IA: An International Journal, 25(1), 515-531

Alavi, M., \& Mansor, S. M. S. (2011). Categories of problems among international students inUniversitiTeknologi Malaysia. Procedia-Social and Behavioral Sciences, 30, 1581-1587.

Amin, A. F. M., Amir, R., Rahman, S., \& Lubis, M. A. (2017). Profile Of Self-Identity AmongstAdolescents: A Study In Johor. Asean Comparative Education ResearchJournal on Islam And Civilization (ACER-J). eISSN2600-769X, 1(1), 124-134.

Andrade, M. S. (2006). International students In English-Speaking Universities: Adjustment Factors. International Education, 5, 24.

Ardi Z, Ibrahim Y, Said A. (2012). Capaian Tugas Perkembangan Sosial Siswa dengan Kelompok Teman Sebaya dan Implikasinya Terhadap Program Pelayanan Bimbingan dan Konseling. Vol. 1 No. 1, March 2012.

Cantres, D. (2015). School-wide factors in New York state high school counseling program readiness. Walden University.

Chris James, Megan Crawford, Izhar Oplatka. (2018). An affective paradigm for educational leadership theory and practice: connecting affect, actions, power and influence. International Journal of Leadership in Education 0:0, pages 1-12.

Cobia, D.C. \& Handerson, D.A. 2003. Handbook of School Counseling. Upper Saddler River: Merrill Prentice Hall.

Collins, S., Hiebert, B., Magnusson, K., \& Bernes, K. (2001). Campus Alberta: A Collaborative, Multi- University Counsellor Training Initiative.

Dimmit, Crey, Crey, Jay. 2007. Using the ASCA National Model to Facilitate School Transitions. Professional Counseling: Alexandria. Vol. 10 Iss. 3.

Dorado Marcio Kinney. (2017). Hearing their voices: the lived experiences \& sacrifices of African-American \&latino males in the boarding school environment.Disertasi. The University of Texas at Austin.

Fathur Rahman. 2009. Reformasi Sekolah dan BK Komprehensif Dalam tinjauanHistoris; KontradiktorisataukahKomplementaris?. Makalah Seminar Nasional "PengembanganPola LayananKomprehensifMenujuKeselarasan Ideal dan Realita". Yogyakarta: Universitas Negeri Yogyakarta.

Gfellner, B. M., \& Armstrong, H. D. (2012). Ego development, ego strengths, and ethnic identity among first nation adolescents. Journal of Research on Adolescence, 22(2), 225-234.

Gysbers, N.C. \& Handerson, P. 2006. Developing and Managing Your School Guidance and Counseling Program. Alexandria: American Counseling Association. 
Hamzah, B. U. (2006). Orientasibarudalampsikologipembelajaran. Jakarta: Bumi Aksara.

Hayah, R. K. (2017, February). Character education in islamic boarding school and the implication to students attitude and critical thinking skills on biodiversity learning. InJournal of Physics: Conference Series (Vol. 812, No. 1, p. 012101). IOP Publishing.

Hus, P. Y. (2003). An Assessment of Counseling Needs of International Students at University of Wisconsim- Stout. Unpublished Master of Science Thesis, University of Wisconsim-Sout, Menomonie.

Kanga, B. M. (2017). Gender comparison in the effectiveness of guidance and counselling services in enhancing students' adjustment to school environment in boarding secondary schools in kenya. International Journal of Advanced Engineering Research and Science (IJAERS), 4(3), 1-14.

Kim, N., \& Lambie, G. (2018). Burnout and Implications for Professional School Counselors. The Professional Counselor, 8, 277-294.

Kjellström, S., Sjölander, P., Almers, E., \&Mccall, M. E. (2017). Value systems amongadolescents: Novel method for assessing level of ego-development. Scandinavian journal of psychology, 58(2), 150-157.

Komalasari, dkk. 2011. Asesmen Teknik Non Tes dalam Perspektif BK Komprehensif. Jakarta: PT Indeks

Lodico, Marguirite. G., Spaulding Dean. T., Voegtle Katherine. H. (2010). Methods InEducational Research From Theory to Practice. United States Of America: Jossey Bass.

Lui, M. (2009). Addressig the Mental Health Problems of Chinese International College Students in The United states. 10.

Margono, S. (2014). Metode Penelitian Pendidikan. Jakarta: Rineka Cipta.

Mudjiran, D. (2007). PerkembanganPeserta Didik. Padang: Dirjen Pendidikan Tinggi.

Nurihsan, Juntika. (2009). Bimbingan dan Konseling Dalam Berbagai Latar Kehidupan. Bandung: Refika Aditama.

Papalia, E.D dan Feldman, R.D. (2014). Experience human development edisi 12 (terjemahan:

Fitriana). Jakarta: SalembaHumanika.

Pavletic, A. C., Dukes, T., Greene, J. G., Taylor, J., \& Gilpin, L. B. (2016). Health services in boarding school: an oasis of care, counseling, and comfort. The Journal of School Nursing, 32(5), 304-314.

Putra, F., \& Ramdani, R. (2014). Ketercapaian Tugas-Tugas PerkembanganRemaja dan Pendidikan Seksual Pada Remaja. JurnalKonseling dan Pendidikan, 2(3), 37-41.

Salvia, J., Ysseldyke, J. E., \& Bolt, S. (2010). Assessment in special and inclusive education. USA: Wadsworth.

Santrock, J. W. (2014). Adolescence fifteenth edition. USA: McGraw-Hill Education.

Sherry, M., Thomas, P., \& Chui, W. (2010). International students: a vulnerable student population. Higher Education, 60(1), 33-46.

Shrivastava. (2013). Principle Of Guidance And Counseling. New Delhi: Kanishka Publisher.

Sovic, S. (2009). Hi-bye friends and the herd instinct: International and home students in the creative arts. Higher Education, 58(6), 747.

Sugiyono. 2014. Metode Penelitian Pendidikan PendekatanKuantitatif, Kualitatif Dan R\&D. Bandung: Alfabeta.

Suherman, Uman. (2010). Manajemen Bimbingan dan Konseling. Bandung:Rizqi press.

Sukmadinata, Nana Syaodih. (2016). Metode Penelitian Pendidikan. Bandung: PT RemajaRosdakarya.

Sunaryo, K., Ahman, Yusuf, S., Nurihsan, J., Karnoto. (2003). Petunjuk Teknis Penggunaan Developmental Task Inventory Siswa Sekolah Menengah Pertama. Bandung: Universitas Pendidikan Indonesia. 
Supriatna, M. (2013). Bimbingan dan konseling berbasis kompetensi orientasi dasar pengembangan profesi konselor edisi revisi. Jakarta: PT RemajaGrafindoPersada.

Suryana, Y., \&Priatna, T. (2008). Metode Penelitian Pendidikan. Bandung: Tsabita.

Utomo, D. P., Prayitno, P., \& Effendi, Z. M. (2017). Pemanfaatan Hasil AUM PTSDL untukPelayananBimbingan dan Konseling. Konselor, 6(3), 105-112. 